\title{
Obituaries
}

Obituaries should be submitted by email to Kate Maynard at k.maynard@nature.com.

All submitted obituaries should be 350 words maximum in length (apart from obituaries for past presidents of the BDA where the length should be $700-800$ words).

Content of the obituary is down to the individual author, and the approval of the family should be given for the obituary prior

to submission to the $B D J$.

\section{JOHN CARSON HARPUR}

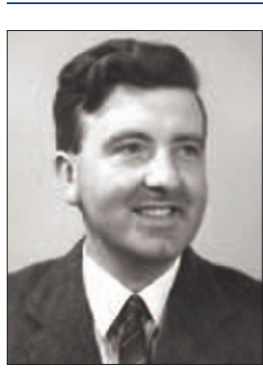

John Harpur LDS

Dip.Orth has passed

away having

enjoyed an inter-

esting, full and

happy life.

John was a

highly respected and successful den-

tist held in high esteem by his patients and colleagues. During his professional life he worked hard to further the interests of the profession in Northern Ireland and in the rest of the UK.

John was born in Calcutta on 17 March 1925 where his father was Commissioner of tea for India. The family returned to the UK and settled in Cheam in 1930. John was educated at Epsom College where he excelled both academically and on the athletics, squash, cricket and shooting teams.

He studied dentistry at the Royal Dental Hospital; after graduating LDS RCS in 1948 he was appointed House Officer and Senior House Officer in oral surgery at the Royal Dental Hospital. Whilst he was a dental student he was a member of the civil defence services during the war and was awarded a defence medal in 1945.

The family moved to Northern Ireland where John established his own dental practice. Subsequently in 1953 he joined the Community Dental Service progressing to Senior Dental Officer. During this time he studied and gained the Diploma in Dental Orthodontics from the Royal College of Physicians and Surgeons in Glasgow.

John served continuously on innumerable committees and boards. This culminated in being elected President of the Community Dental Officers Group of the BDA for the UK from 1980-1981. He served on the national CCCDS executive, the BDA Northern Ireland Council and the BDA Northern Ireland committee. He was delighted to be honoured as a lifetime member of the BDA.

From 1990 John and his wife Maud enjoyed a happy retirement in which John continued his love of travel as well as skiing, golf, gardening and spending time with their family.

During his career John remained very much a committed family man and was enormously proud of Maud and their three children John, a chartered accountant, Charmian, a dentist, and Brian, also a chartered accountant. Those who knew him will remember him as a kind and devoted husband, father and grandfather.

\section{Harpur}

\section{ERIC JAMESON}

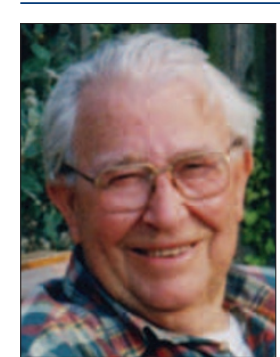

Eric Jameson, who died peacefully on Wednesday 25 May aged 95 was, like his father Andrew, a well known and highly respected dental surgeon in general dental practice in Bishop Auckland.

Educated at Cockton Hill Primary School and King James's Grammar School in Bishop Auckland, he graduated from the Sutherland Dental School, Newcastle upon Tyne in 1937. At the outbreak of WW2 he volunteered for the Army and served in the Royal Army Dental Corps. Posted to the Middle East he would spend most of his army career in North Africa. Discharged with the substantive rank of Major, he joined his father in general practice in No. 6 The Market Square, Bishop Auckland, and married Jean MacClennan in 1951, eventually taking over the practice when Andrew retired. During this time Eric held honorary appointments at Bishop Auckland Emergency Military (later the General) Hospital and at Marks and Spencer. He retired from dental practice in 1990.

An active member of Round Table, Rotary and Bishop Auckland Golf Club, he also had a keen interest in photography, electronics and mechanical engineering.

His wife Jean died in 2002 and he is survived by three children, Andrew, Carolyn and Paul.

George D. Jameson 